\title{
Agronomic characteristics of pumpkin fruits of "Tetsukabuto"hybrid as a function of 2,4-D doses
}

\author{
'University of Tocantins State, Palmas, Brazi \\ ${ }^{2}$ Federal University of Tocantins, Gurupi,, Brazil. \\ ${ }^{3}$ São Paulo State University, Botucatu, Brazil \\ ${ }^{4}$ Católica University of Tocantins, Palmas, Brazil \\ ${ }^{*}$ Corresponding author, e-mail:
}

Flávia Fernandes Ribeiro de Miranda' ${ }^{1}$, , lldon Rodrigues do Nascimento ${ }^{2}$ Prínscilla Pâmela Nunes Chaves ${ }^{3}$, Cid Tacaoca Muraishi ${ }^{4}$, Daisy Parente Dourado ${ }^{1}$

\begin{abstract}
Due to the short flowering period of the pumpkin hybrid 'Tetsukabuto', a poor pollination may influence the fruit production. In thissense, the objective of this study was to evaluate agronomic characteristics of the pumpkin hybrid (Tetsukabuto) as a function of 2,4-D doses as phytohormonal inducer. The experiment was conducted in the field, in a randomized block design with four replications and five plants per plot. It was established with eight treatments, seven of them increasing doses of 2,4-Dichlorophenoxyacetic acid (187.5, 200, 212.5, 225, 237.5, 250 and 262.5 $\mathrm{mg} \mathrm{L}^{-1}$ ) and a control (flowers fertilized with pollen). At 110 days after sowing it was made a fruit harvest, evaluating the following characteristics: yield, fruit mean weight, texture of bark, fruit shape and cycle. The fruits mean weight, yield and days from planting to harvest with the use of 2,4-D were superior to natural pollination. Increasing the dose of 2,4-D resulted in an increase in yield and fruit mean weight until to dose $250 \mathrm{mg} \mathrm{L}^{-1}$. There was a reduction in the cycle culture with increasing in the 2,4-D doses.
\end{abstract}

Keywords: Cucurbita maxima, Cucurbita moschata, phytohormone, yield

\section{Introduction}

The pumpkin (Curcubita spp.) is originated from the central region of Mexico and South America (Nee, 1990; Wilson et al., 1992). Due to its alimentary importance pumpkin is widely known and cultivated worldwide for human and animal alimentation because it is rich in fiber, vitamins $A$, $C$ and vitamins B complex.

Among the cultivated pumpkins species, the Tetsukabuto hybrid, also called Japanese pumpkin or kabutiá, resulted from pumpkin $\mathrm{x}$ moranga crossbreeding. The good acceptance of the 'Tetsukabuto' hybrid is attributed to the fact that it has fruits that present pulp of orange coloration, thick, lean, with total solids content ranging from 12 to $18 \%$. It is also attributed to the wide adaptability, precocity, uniformity and post-harvest resistance to handling and transport. Year by year the 'Tetsukabuto' hybrid expression has been increased, when compared to the common pumpkin (Tavares, 1999).

The "Tetsukabuto" pumpkin hybrid has sexual expression of the monoicous type producing female and male flowers in the same plant. They are commonly sterile males, since the male flowers abort or do not produce pollen, so they are functionally gynoics (Cheng \& Gavilanes, 1980), thus for fruiting it needs, the synchronized planting with a pollen donor species as C. moschata or C. maximus, enabling to occur cross- 
pollination (Sonnenberg, 1985) or even make use of techniques to induce parthenocarpy through the application of growth regulators (Pasqualetto et al., 2001).

The efficiency of the fruiting process is directly linked to pollination, but the reduction in fruit production may be due to conditions such as low temperatures, strong winds or continuous rains that reduce the activity of pollinating insects (Pasqualetto et al., 2001). Honey bees, especially those of the Appis genus are the insects that, in favorable conditions, pollinate the cucurbits and they have prefer the early morning period, with a higher concentration of visits between 6 and 10 hours when the flowers are open and receptive to fertilization (Lopes \& Casali, 1982). The pollen viability grains in pumpkins is approximately $92 \%$ at the flowers anthesis, reducing to $75 \%$ when they close and then to $10 \%$ at one day after anthesis, mainly due to the dehydration of the pollen grain (Cardoso, 2005).

In the Tetoukabuto hybrid commercial planting, one of the techniques adopted to overcome the failures in the pollination process and to ensure the fruit development, using phytoregulators of the auxin group, which, when pulverized in the flower, ensure the formation of the fruit by the process called parthenocarpy, without pollination requirement. Using this practice, the productivities are higher than those obtained with the use of a pollen donor (Franco, 1999).

The Brazilian average yield is estimated between 9 and 12 tons per hectare, but it can reach 25 tons per hectare when using products with phytohormonal properties to stimulate fruit development via parthenocarpy. When comparing the need for pollinators, the use of products with phytohormonal properties $(2,4$ D: 2,4-dichlorophenoxyacetic acid) is relatively inexpensive, since with $15 \mathrm{~mL}$ commercial product 2,4-D is enough to spray a cultivated hectare with pumpkins (Franco, 1999).

The replacement of natural pollination by synthetic phytohormone to promote fruiting, eliminates the need to plant pollinating cultivars, reducing the effects of climatic adversities on bee pollinating activity.

This way, the objective of this work was to evaluate the agronomic characteristics of pumpkin fruits of Tetsukabuto hybrid as a function of 2,4-D doses as phytohormonal inducer.

\section{Material and Methods}

The experiment was conducted at the Federal University of Tocantins - UFT, Campus of Gurupi, in the southern region of Tocantins state, with $280 \mathrm{~m}$ altitude (latitude $11^{\circ} 43^{\prime} 45$ "and longitude $49^{\circ} 04^{\prime} 07^{\prime \prime}$ ). The climatic classification according to Köppen (1984) characterizes the region as type BlWAa, humid with moderate water deficiency. The mean annual temperature is $29.5^{\circ} \mathrm{C}$, with a mean annual rainfall of 1.804 $\mathrm{mm}$.

The experimental design was a randomized block design with four replications. Each plot was composed of five plants (spaced $2 \mathrm{~m}$ between plants and $2.5 \mathrm{~m}$ between rows). Eight treatments consisted of seven increasing doses of 2,4-D in the following concentrations: $187.5 ; 200 ; 212.5 ; 225 ; 237.5 ; 250 ; 262.5 \mathrm{mg} \mathrm{L}^{-1}$ and the control obtained from artificial pollination with pollen.

The experiment was implemented in May 2011 , with the planting of the "Tetsukabuto" hybrid cultivar Kyoto ${ }^{\circledR}$ (Feltrin). The sowing was done in previously fertilized pits, sowing two seeds per pit in soil prepared with ploughing, harrowing and furrowing, with the fertilizer previously incorporated throughout the planting line. Preplanting fertilization was performed according to the physical-chemical analysis and crop requirement, using $150 \mathrm{~kg} \mathrm{ha}^{-1}$ of formulation 05 25-15. At 30 and 45 days after planting, the cover fertilizations were carried out with $60 \mathrm{~g}$ of urea and potassium chloride, respectively.

The commercial product DMA 806 BR $^{\circledR}$ DowElanco was used as the 2,4-D source. The 2,4-D solution was prepared with distilled water and stored in a fresh and shaded place, being renewed every 8 days. The female flowers were protected one day before anthesis. The applications of the different concentrations of 2,4-D solutions were carried out with a mini hand sprayer, using a nozzle of about $5 \mathrm{ml}$ at the inner part of the flower in the early morning (from 6 to 9 a.m.). After sprayed, flowers were again protected with paper bags to avoid possible 
contaminations.

The control pollen was obtained from plants of the cultivar Menina Brasileira planted 18 days before experiment installation at a site far from the experimental area.

The management and control of weeds, pests and diseases was carried out as recommended by Filgueira (2003). Irrigation was performed by sprinkler whenever necessary. At 110 days after sowing the fruits were harvested, evaluating the following characteristics:

- YieldFruit yield (PROD): obtained by the sum of the weight of the fruits harvested from the plants of the useful area of each plot and then converted to ton $\mathrm{ha}^{-1}$;

- Mean fruit weight (MFW): obtained by the total weight of the fruits harvested in each useful plot, divided by the number of fruits of each useful plot, given in kg;

- Peel texture (PEELTEXT): obtained visually using a scale of notes, in which: 1 - fruits with smooth-peel; 2 - fruit with poorly wavy Peel; and 3 - fruits with wavy peel;

- Fruit format (FRUITFORM): obtained visually by a scale of notes, in which: 1) globular shaped fruits; 2) fruits with flattened globular shape; 3) fruits with spherical shape; 4) fruits with cylindrical shape; and 5) fruits with elongated shape;

- Crop cycle: obtained by counting the days from planting to harvest, considering the harvest point when the plot has reached more than $50 \%$ of fruits in the mature stage.

With the mean values of each replicate for each treatment, analysis of variance was performed and the treatments were compared with orthogonal contrasts by "t" test, and for the effect of doses, regression equations were adjusted by the statistical program SigmaPlot.

\section{Results and Discussion}

Table 1 presents a summary of the variance analysis for the agronomic characteristics evaluated. There was significance at $1 \%$ of probability by the $F$ test for the yield and crop cycle characteristics, and at 5\% of probability for mean fruit weight and peel texture, and no significance for fruit format.

Table 1. Summary of the variance analysis for yield (PROD), mean fruit weight (MFW), peel texture (PEELTEXT), fruit format (FRUITFORM) and days for harvest (CYCLE) in "Tetsukabuto" hybrid pumpkins produced as a function of 2,4$D$ doses

\begin{tabular}{ccccccc}
\hline \multirow{2}{*}{ Variable } & \multirow{2}{*}{ D.F. } & \multicolumn{5}{c}{ Q.M. } \\
\cline { 3 - 7 } & & PROD & MFW & PEELTEXT & FRUITFORM & CYCLE \\
\hline Blocks & 3 & 1.67 & 0.05 & 0.05 & 0.26 & 7.08 \\
Treatments & 7 & $54.08^{* *}$ & $0.14^{*}$ & $0.35^{*}$ & $0.14^{\text {ns }}$ & $82.57^{* * *}$ \\
Residue & 18 & 8.57 & 0.05 & 0.15 & 0.13 & 3.66 \\
\hline V.C. (\%) & & 20.10 & 11.02 & 19.22 & 31.73 & 1.88 \\
Total mean & 14.57 & 2.18 & 2.04 & 1.71 & 101.60 \\
$*_{*}^{* * *}$ and ${ }^{n s}$ meaning to $p<0.05$ and $p<0.01$ of probability and not significant respectively, by the test $\mathrm{F}$.
\end{tabular}

Yield increased according to increment in the 2,4-D doses, reaching a maximum value at 2,4-D dose of $240 \mathrm{mg} \mathrm{L}^{-1}$. This result showed that this dose tended to raise yield to $16.17 \mathrm{t} \mathrm{ha}^{-1}$, and decreasing when $262.5 \mathrm{mg} \mathrm{L}^{-1}$ of the product was applied (Figure 1).

When compared to the control, there was an increase of $4.73 \mathrm{tha}^{-1}$ in the yield (Table 2). These results are similar to the studies developed by Pereira (1999), who verified that doses ranging from 200 to $250 \mathrm{mg} \mathrm{L}^{-1}$ of 2,4-D promoted the greatest fruit yields.

However, Oliveira (2002) observed that plants which received doses above $250 \mathrm{mg} \mathrm{L}^{-1}$ of 2,4-D, presented symptoms of phytotoxicity, reducing the yield. This fact ratifies the observations that the productivities obtained through the system of parthenocarpic fruiting with the use of phytohormone are usually larger (around 50 to $200 \%$ ) than the process of entomophilous fruiting (Franco, 1999). Casillas et al. (1986) argued that phytohormones are efficient when applied in small doses, favoring the good performance of vital plant processes with the objective to increase the production.

The mean fruit weight showed the same tendency observed for yield, rising until $250 \mathrm{mg}$ $\mathrm{L}^{-1}$ of 2,4-D, and decreasing when the dose was increased to $262 \mathrm{mg} \mathrm{L}^{-1}$ of the product. Hathout et al. (1993), observed that the use of auxin-based 
phytohormones in concentrations between 200 and $250 \mathrm{mg} \mathrm{L}^{-1}$ induced flowering and fruiting in tomato plants, increasing the number and mass of fruits. The concentrations above $250 \mathrm{mg} \mathrm{L}^{-1}$, resulted in the reduction of the mean fruit weight, similar to that observed in this study.

Pedrosa (1982) reports that the "Tetsukabuto" hybrid pumpkin has a cycle ranging of 95 to 110 days from planting to harvesting. In the evaluated experiment, it was observed that the control had a longer cycle, with a mean of 111 days and the highest dose $262.5 \mathrm{mg} \mathrm{L}^{-1}$ of 2,4$\mathrm{D}$ tended to present a minor mean with a cycle of 95 days. In general, it was observed that the increase of the 2,4-D dose promoted reduction in crop cycle (Table 2, Figure 2).

As for peel texture, 2,4-D doses promoted a greater expression of this characteristic, with the mean variation between 2.00 and 2.25, higher than the mean of control with 1.62 (Table 2). Based on these results, it was verified that the use of 2,4-D promotes greater roughness of the fruit peel when compared to the use of pollen as an inducing agent for fruit development.

For the fruit format characteristic, there was no difference when the 2,4-D doses were compared to the control. By the used note scale, the majority of fruits presented a mean of 1.00 to 1.25 , corresponding to a globular fruit shape, tipycal of the hybrid "Tetsukabuto".

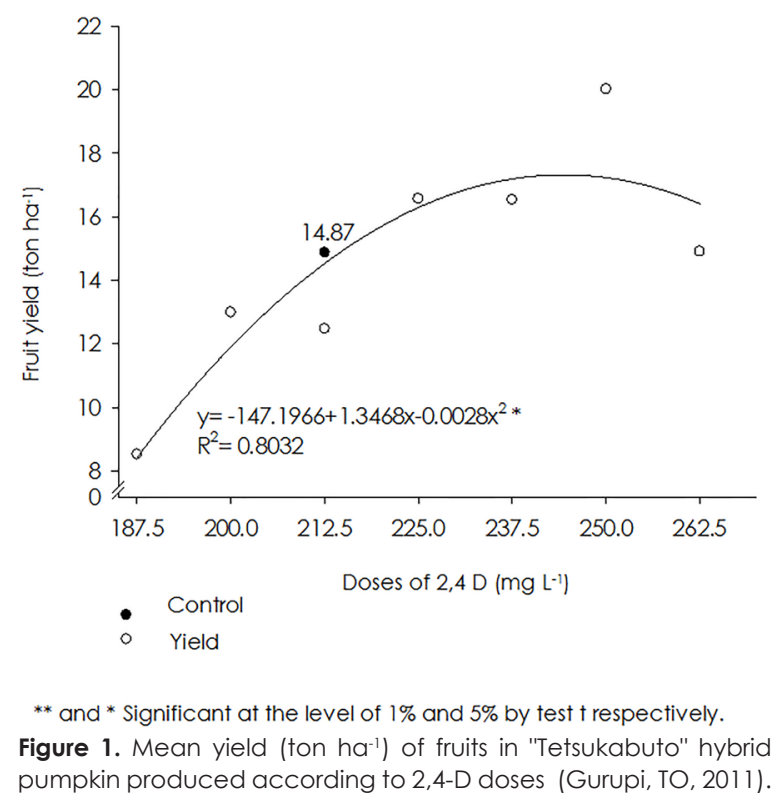

Table 2. Mean values for yield (PROD), mean fruit weight (MFW), peel texture (PEELTEXT), fruit format (FRUTFORM) and days for harvest (CYCLE) in hybrid 'Tetsukabuto' pumpkin produced as a function of 2,4-D doses.

\begin{tabular}{|c|c|c|c|c|c|c|c|c|c|c|}
\hline \multirow{2}{*}{ Characteristics } & \multicolumn{7}{|c|}{ 2,4-D Doses (mg L-1) } & \multirow{2}{*}{ Regression equations } & \multirow{2}{*}{$\mathbf{R}^{2}$} & \multirow{2}{*}{ evidence } \\
\hline & 187.5 & 200 & 212.5 & 225 & 237.5 & 250 & 262.5 & & & \\
\hline PROD & $8.51^{*}$ & 12.99 & 12.47 & 16.57 & 16.52 & $18.73^{*}$ & 14.90 & $Y=-147.20+1.35 X-0.0028 X^{2}$ & 0.80 & 14.87 \\
\hline MTFW & 2.06 & 1.85 & 2.10 & 2.26 & $2.43^{*}$ & $2.34^{*}$ & 2.22 & $Y=2.41-0.57 x+0.20 x^{2}-0.01 x^{3}$ & 91.1 & 1.74 \\
\hline BATEXT & $2.25^{*}$ & $2.00^{*}$ & $2.25^{*}$ & $2.00^{*}$ & $2.00^{*}$ & $2.00^{*}$ & $2.25^{*}$ & $Y=2.04$ & - & 1.62 \\
\hline FRUTFORM & 1.00 & 1.25 & 1.25 & 1.00 & 1.00 & 1.00 & 1.25 & $Y=0.42+0.80 x-0.24^{2}+0.02 x^{3}$ & 90.2 & 1.12 \\
\hline CYCLE & $99.75^{*}$ & 106.50 & 105.75 & 106.25 & $99.50^{*}$ & $98.5^{*}$ & $95.00 *$ & $Y=-130.17+2.19 X-0.0051 X^{2}$ & 81.5 & 111 \\
\hline
\end{tabular}
pollination).

\section{Conclusions}

The fruit yield of the pumpkin hybrid increased in response to 2,4-D doses, reaching the higher yield at $240 \mathrm{mg} \mathrm{L}^{-1}$.
The increment in the 2,4-D doses resulted in an increase in the mean weight and the fruits roughness, resulting also in the reduction of the crop cycle. 


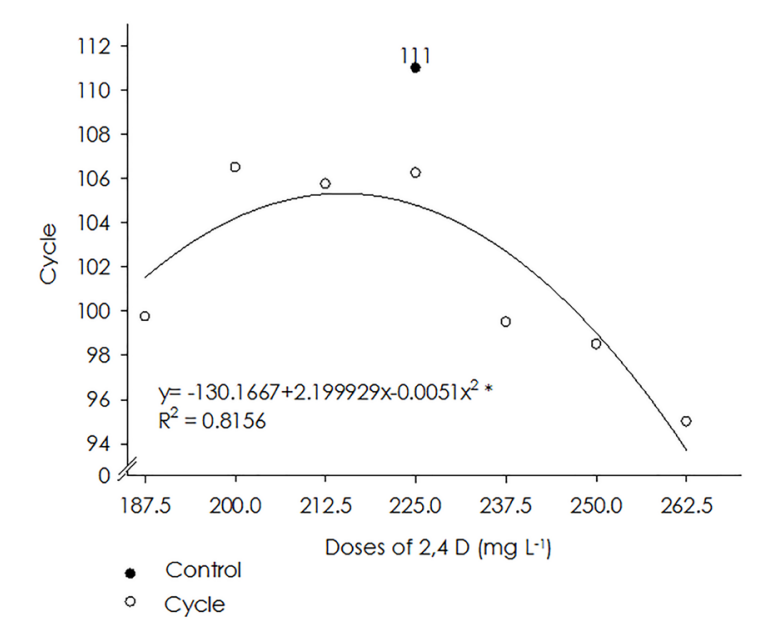

** and * Significant at $1 \%$ and $5 \%$ levels by the t test respectively.

Figure 2. Cycle of the cultivation in hybrid pumpkin "Tetsukabuto" produced as a function of 2,4-D doses.

\section{References}

Cardoso, A.I.I. 2005. Polinização manual em abobrinha: efeitos nas produções de frutos e de sementes. Horticultura Brasileira 23: 731-734.

Casillas, J.C., Londono, J., Guerreiro, H., Buitrago, L.A. 1986. Análisis Cuantitativo de la aplicación de cuatro bioestimulantes em el cultivo rábano (Raphanus sativus L.). Acta Agronomica 36: 185195.

Cheng, S.S., Gavilanes, M.L. 1980. Microsporogênese e macho-esterilidade da moranga híbrida interespecífica Tetsukabuto. In: Congresso Brasileiro de Olericultura, 20, Brasília, Brazil. CD-ROM

Filgueira, F.A.R. 2003. Novo manual de olericultura: agrotecnologia moderna na produção e comercialização de hortaliças. Editora UFV, Viçosa, Brazil. 412 p.

Franco, M. 1999. Abóboras: fitohormônio aumenta a produção. Suplemento do Campo do Jornal de Brasília. Ano 12, n. 594.

Hathout, T.A., Shetawi, S.A., Khallal, S.M. 1993. Effect of modes of application of some growth regulators on the physiology of tomato plants: III. Effect of nicotinamide on morphology growth, metabolism and productivity. Egyptian Journal of Physiological Sciences 17: 183-200.

Köppen, W. 1984. Climatologia - conune studio de los climas de la tierra. México, Fondo de Cultura Economica. 479p.

Lopes, J.F., Casali, V.W. 1982. Produção de sementes de cucurbitáceas. Informe Agropecuário 865 - 68 .

Nee, M. 1990. The domestication of Cucurbita (Curcubitaceae). Economic Botany 44: 58-68.
Oliveira, E.C.M., Valle, R.H.P. 2002. Aspectos microbiológicos dos produtos hortícolas minimamente processados. Higiene Alimentar 1 1:78-79.

Pasqualetto, A., Silva, N.F., Ordonez, G.P., Barcelos, R.W. 2001. Produção de frutos de abóbora híbrida pela aplicação de 2,4-D nas flores. Pesquisa Agropecuária Tropical 31: 23-27.

Pedrosa, J.F., Ferreira, F.A., Casali, V.W. 1982. Abóbora, morangas e abobrinhas: cultivares e métodos culturais. Informe Agropecuário 8: 2426.

Pereira, W. 1999. Recomendações para a frutificação da abóbora híbrida tipo Tetsukabuto: Uso de polinizadores e reguladores de crescimento de plantas. Brasília: Embrapa Hortaliças. 7p. (Embrapa Hortaliças, Comunicado Técnico, 12).

Sonnenberg, P.E. 1985. Olericultura especial, $2^{a}$ parte "cucurbitáceas". 3. ed. Escola de Agronomia/UFG, Goiânia, Brazil. 149p.

Tavares, C.A.M. 1999. Abóbora Tetsukabuto. Seed News 13: 24.

Wilson, H.D., Doebley, J., Duvall, M. 1992. Chloroplast DNA diversity among wild and cultivated members of Cucurbita (Cucurbitaceae) Theor Appl Genet 84:859-865. 